\title{
The Trouble with Diversifying the Faculty
}

\author{
KEY WORDS \\ United States, race, \\ multiculturalism, \\ diversity, university, \\ politics of difference, \\ social class, academic \\ staff, educational \\ system
}

\begin{abstract}
Michaels Walter Benn, The Trouble with Diversifying the Faculty [Kłopoty ze zróżnicowaniem wydziału]. Kultura - Społeczeństwo - Edukacja nr 1, 2012, Poznań 2012, pp. 9-19, Adam Mickiewicz University Press. ISBN 97883-232-2470-9

This article presents the problem of politics of difference realized within the American educational system, with a special emphasis on higher education. This politics is according to the author based on putting in the center of all educational actions the idea of diversity, as well in creating academic institutions. This key idea becomes in the American context a special significance, regarding the fact that the American society is based on ideology that celebrates multiculturalism and diversity as such. This article presents also an important for the contemporary situation in the United States problem of combining cultural and ethnic diversity on the economical category of difference between various classes. Furthermore, it seems to be more significant in the light of the economic crisis in recent years that affected also American education in the same extent.
\end{abstract}

The widespread sense that faculties at US colleges and universities need to be more diverse is tied to the sense that the students at US colleges and universities have become more diverse, which indeed they have. In 1971, entering freshmen were overwhelmingly (90.9 percent) white, 7.5 percent were black; Asians and Latino/as, at 0.6 percent, were almost invisible. Today, according to the Chronicle of Higher Education's annual survey of freshmen at four-year colleges, 73.1 percent are white, 11 percent are black, 8.9 percent are Asian, and 9.7 percent are Latino. Of course, these numbers don't amount to complete success: Latinos and Latinas are underrepresented, and blacks are also still slightly underrepresented. Furthermore, if we take numbers from more selective colleges, even the 11 percent for blacks begins to look a little high. Northwestern, for example, is only about 5 percent black;

* Reprinted with permission from "Liberal Education", vol. 97, no. 1. Copyright 2011 by the Association of American Colleges and Universities. 
the University of Illinois at Urbana-Champaign is closer to 7 percent (US College Search). So here, blacks are significantly underrepresented.

But they are not underrepresented because they are black. On the contrary - this is what scholars in the field call the "net black advantage" - once "baseline economic disparities are discounted", African Americans are more likely to attend four-year colleges than white students are. What this means, as the authors of the study "Racial Inequality and College Attendance" say, is that the idea that "African American educational disadvantage is rooted in cultural deficiencies and/or resistance to the mainstream educational system" is pretty much nonsense (Charles, Roscigno, Torres, 2007) ${ }^{1}$. And, of course, what it also means is that the underrepresentation of African Americans in colleges and universities has nothing to do with those universities keeping out African Americans (or, for that matter, Hispanics and Native Americans). Universities don't keep out minority students; they keep out poor students.

Indeed, the increase in diversity in higher education over the last forty years has been matched by an increase in wealth. In 1971, the median income of entering freshmen at the 297 colleges participating in the American Freshmen Survey was 46 percent above the national average; by 2007, it had climbed to 60 percent (Pryor et al., 2007). As a result, poor students of all races are scarcer than blacks or Latinos. So places like Northwestern may be only 5 percent black, but since, according to Richard Kahlenberg (2007), only around 3 percent of the students in the 146 most selective colleges and universities come from the bottom socioeconomic quarter of the American population, you still have a better chance of meeting a black kid than you do of meeting a poor one on their campuses.

\section{The two-tier professoriate}

Thus the question about who should be on the faculty is a question about who should teach the rich kids, and although no one has argued that professors should be both as diverse as their students and as rich, the incomes of the teachers have, in fact, risen. The median household income in 2008 was a little over $\$ 52,000$; according to a 2009 survey by the American Association of University Professors (AAUP), the average salary for full-time faculty was $\$ 79,439$. Professors, like their students, are about 60 percent above the median.

1 In fact, when you net out the economics, the disadvantage in college attendance of other underrepresented groups like Native Americans and native-born Hispanics is also virtually eliminated. Furthermore, the difference between native blacks and immigrant blacks (who attend selective colleges in a much higher proportion than native blacks) also disappears when socioeconomic status is netted out (see Bennett, Lutz, 2009). 
Or at least some of them are. The AAUP survey doesn't include contingent faculty, and any number that doesn't include contingent faculty is ignoring the vast majority of American faculty members. For just as the increase in student diversity and student wealth have tracked each other over the last forty years, the increased reliance on contingent faculty has tracked them both. In 1975, almost 57 percent of faculty were tenured or on the tenure track; today that percentage has been almost cut in half, and the percentage of nontenure-track faculty has gone from 43.2 percent to 68.8 percent (AAUP 2010). The people who work these jobs do not make anything like $\$ 79,000$ a year; they don't even make anything like the median income of $\$ 52,000$.

At my university, the University of Illinois at Chicago (UIC), for example, adjuncts on nine-month contracts, teaching six courses a year, make between $\$ 26,788$ and $\$ 30,900$, a salary that, according to the Chronicle of Higher Education, is "high among those who work outside the tenure track in the region" (June 2009). Even at the high end, however, it's more than a thousand dollars below the minimum $\$ 6,200$ per course section called for by the Modern Language Association (2008). This year, we have hired (on one-year contracts) thirty-six adjuncts, which is nothing like the two-thirds of the faculty they constitute nationally (many of whom teach at community colleges) but is, since the number of tenured and tenure-track faculty in our department is thirty-five, a slight majority of the UIC English department. And, since the adjuncts, with no research responsibilities, have a heavier teaching load than do the tenured and tenure-track faculty, their courses constitute a very large majority of the teaching our department does. Indeed, since at UIC the number of those on the tenure track has declined over the last twenty years, while the number of students has grown, it would be completely impossible for the university to staff our courses without adjuncts. Thus, as American college students have become, on the average, richer, the people who teach them have become, on the average, poorer. If you assume that the average UIC tenure-track professor of English makes the national average and you take her salary and average it with what our lecturers make, what you get is a faculty that earns about $\$ 54,000$ - more like 2 percent above the median than 60 percent.

But just as the colleges themselves worry much more about the student body's diversity than about its wealth, they worry much more about the faculty's diversity than about its poverty. At UIC, for example, we have a commitment to "increasing the numbers of underrepresented faculty" and we have administrators who, within the best of their ability in difficult times, are seeking to honor that commitment ${ }^{2}$.

${ }^{2}$ It's also, true, I'm glad to say, that at UIC we are at least a little bit worried about the situation of our adjuncts, and I am currently cochairing a committee to see what can be done about it. "Liberal Education" (Winter 2011) The Trouble with Diversifying the Faculty 4/8/11 4:54 PM http://www. aacu.org/liberaleducation/le-wi11/LEWI11_Michaels.cfm Page 8 of 8 a committee to see what can be done about it. 
So although we don't have very many searches, when we do, they're often targeted at scholars of color or toward areas - like African American Studies or Latino literature - where we can plausibly hope that the successful candidate will embody as well as profess his or her subject, since it is, after all, the underrepresentation of bodies, not professional specialties, that our commitment to diversity is seeking to rectify. And insofar as searches like these are successful, our tenure-track faculty may continue to dwindle but it will do so in colors that come closer to matching those of the American population and at salaries that continue to exceed those of the American population.

Meanwhile, however, much of our teaching will be done by people whose salaries trail the median and whose colors we don't care about. Which is to say, we are being made into precisely the kinds of employees neoliberal managers love. On the one hand, most of our work is done by cheaper and less secure labor (the adjuncts) and, on the other hand and even in the depths of the Great Recession, our commitment to social justice (the faculty of color) remains intact. The advantages of the two-tier professoriate, in other words, are both material and moral: on the bottom tier, a flexibilized work force; on the top tier, a diversified one. And although the bottom tier at present is nowhere near as diverse as the top, that's not really a problem, since no one of any race really wants to be on the bottom. Success here consists only in diversifying the elite and thus achieving the new American Dream: not a more equal society but a society in which inequality is more evenly distributed, in which a few more of the winners are people of color and a few more of the losers are white guys.

This is the dream Adolph Reed is describing when he says that we live today "under a regime that is capable of simultaneously including black people and Latinos, even celebrating that inclusion as a fulfillment of democracy, while excluding poor people without a whimper of opposition" (Reed, 2009b). His point is not, of course, that we should be unhappy because this regime challenges white privilege; it's that we should be unhappy because it consolidates class privilege. Indeed, it not only consolidates class privilege, it enhances it. For the replacement of the idea of equality with the ideal of proportional inequality has taken place at the very moment - beginning in the late 1970s - in which inequality has been rapidly on the rise. And as the rich have become richer while everyone else has not, what we've developed is an institutional morality that objects to the inequalities produced by prejudice and discrimination but not to the ones produced by competitive markets. The "triumph of neoliberalism", as Reed puts it, is the idea that "only inequalities resultant from unfavorable treatment based on negatively sanctioned ascriptive designations like race qualify as injustice" (Reed, 2009a: 271). Thus markets win on both the material and the ideological levels. Neoliberalism creates greater disparities between the rich and the rest, and it teaches us 
that those disparities, so long as they're produced by markets and not by discrimination, are deserved.

It's in this context that we can recognize the fundamentally conservative and antiegalitarian character of the call to diversify the faculty and, indeed, of the American university system in general. The University of Michigan, a determined and at least partially successful (notably in Grutter v. Bollinger) combatant in the fight for diversity, is emblematic here. In 2004, Kahlenberg (2010) points out, as the university "was celebrating its victory in the Supreme Court, this national symbol of racial diversity had more students from families making in excess of $\$ 200,000$ per year than families earning less than the national median of $\$ 53,000$ a year"3. In other words, the university's commitment to "racial and ethnic diversity" and especially "to the inclusion of students from groups which have been historically discriminated against $[\ldots]$ who without this commitment might not be represented in our student body in meaningful numbers" did not extend to the students who are most underrepresented at Michigan and at its private competitors: the poor. ${ }^{4}$. That is, the attempt to open the university's doors to people of color has taken precedence over the attempt to open them to people without money. Indeed, judging by the results, there hasn't really beenany attempt to open them to people without money, or, for that matter, even to people with just a normal amount of money since, as David Leonhardt (2004) has observed, "at the most selective private universities across the country, more fathers of freshmen are doctors than are hourly workers, teachers, clergy members, farmers or members of the military - combined". But, of course, no one could even have dreamed of suing Michigan on behalf of the children of hourly workers. There may be a constitutional question about whether raceconscious admissions policies discriminate against white people, but it's definitely not against any law to give preferences to the rich.

Just as it's not against any law to underpay the people who teach their children - which is not to say that the benefits of faculty diversity are reserved only for those universities whose enthusiasm for combating racism and sexism sits comfortably alongside their indifference to combating exploitation. On the contrary, the advantages of diversity are almost equally vivid in situations where both the students and the faculty are well-off since here, too, the institution's sense of its own virtue

\footnotetext{
${ }^{3}$ More generally, although Michigan does well in admitting minority students, it does badly in admitting low-income students: "Overall, nearly 39 percent of students attending Michigan colleges and universities receive Pell Grants. Yet among University of Michigan students, only 13 percent receive Pell Grants, an indication that low-income students in the state are going elsewhere" (Dervarics, 2010).

4 Source: the proof brief of defendants-appellants in Grutter v. Bollinger (no. 01-1447) filed with the United States Court of Appeals for the Sixth Circuit on May 16, 2001, http://www.vpcomm. umich.edu/admissions/legal/grutter/grutter_appeal.html.
} 
is largely dependent on the idea that rich people getting paid to help other rich people make sure that their wealth and status get transmitted from one generation to the next is a good thing as long as the rich people in question aren't all white and male. Indeed, in this respect, our universities, despite our tendency to think of them as the most liberal of institutions, are just like almost every other American institution of the uppermiddle class. No one can plausibly think of banks as liberal institutions, but the annual Vault ranking of the "50 Most Prestigious Banking Firms" takes diversity into account, and the number one firm last year - both in diversity and overall - was Goldman Sachs.

Of course, the recent suit alleging discrimination against women at Goldman Sachs and complaining of their "stark' underrepresentation" in management "just 29 percent of vice presidents, 17 percent of managing directors, and 14 percent of partners" (Mangan, 2010) - may have a negative impact on its rankings for this year. But it's the logic according to which the complaint is conceived rather than its validity that makes the relevant point. If Lloyd Blankfein's $\$ 9$ million bonus were instead going to Jane Doe, would that make Goldman Sachs a more liberal institution? Would the United States be a more egalitarian country if the beneficiaries of our increasing inequality included more women?

\section{Reproducing inequality}

University leaders regularly puzzle over the fact that, as President Drew Faust (2008) of Harvard has put it, their undergraduates "are going in such numbers... into finance, consulting, i-banking". But it's hard to see why anybody should be surprised. After all, it was President Faust herself who at her installation congratulated our universities on being engines of "the expansion of citizenship, equality and opportunity - to blacks, women, Jews, immigrants, and others" (2007). And we've already seen who the others aren't. The only difference between the banks and the universities is that at Goldman Sachs, where the goal is to make the kids even richer, they don't just appreciate diversity; with "a global client base that reflects a multitude of cultures", they "leverage" it (QS). So if 39 percent of the Harvard graduating class is going into banking and finance, it's not an anomaly. It's because they've learned very well the lessons in social justice (the lessons of student and faculty diversity) that Harvard has taught them, and they'll fight just as hard to make those lessons a reality on Wall Street as they have in Cambridge. Even more striking than the bad news about 39 percent of the students going into banking, however, is what President Faust thinks of as the good news, namely, that a significant number (thirty-seven) have "signed on with Teach for America". The symbiosis with Goldman Sachs et al. is perfect, since no cause is more beloved of 
Wall Street than destroying the little that's left of the American union movement today, and "educational reform" (led by Teach for America and the charter school movement) is at the heart of that effort. Thus, the "Wall Street Journal" describes the fact that there are more college graduates wanting to join Teach for America (TFA) than there are schools wanting to hire them by declaring it a "tragic lost opportunity" produced by "union and bureaucratic opposition" (A10). The "Journal" doesn't mention the studies showing that "the students of novice TFA teachers perform significantly less well in reading and mathematics than those of credentialed beginning teachers" (Heilig, Jez, 2010). And the well-meaning college administrators, delighted that more of their charges are going off to do good, don't say much about the fact most of them won't do it very well or for very long. More than 80 percent of TFA teachers leave after three years.

But as Michelle Rhee, one of the heroes of the recent film Waiting for Superman, likes to say, it's really all about the adults, not the kids. If, for instance, you juxtapose the claims the film makes on behalf of Wall Street's favorite charter school, the Harlem Children's Zone (HCZ), with the reality of its performance - starting with the fact that just 15 percent of its seventh graders passed the 2010 New York reading test - it's not hard to see that HCZ, although even more beloved of Wall Street than Teach for America (Goldman Sachs just gave HCZ \$20 million [Otterman, 2010b]), is not much better at actually educating children. And it's even easier to see that Jeffrey Canada's solution to HCZ's recent failure on the reading tests - "Several teachers have been fired as a result of the low scores, and others were reassigned" (Otterman, 2010a) - is closer to the heart of school reform than is any actual improvement in the kids' education, although this is an insight that comes more easily to conservatives who know they're conservative that it does to high-minded liberals. Thus, outraged though he might be by "the plight of children trapped in failing schools with lousy, union-protected teachers," the rightwing columnist Ross Douthat (2010) is skeptical about the ability of school reform to do the main thing school reformers claim it can do, namely, significantly raise test scores. But that's OK, because even though reform won't "turn every American child into a test-taking dynamo", if it accomplishes "the feat" of creating "a more cost-effective system", that's something "well-worth fighting for". Douthat articulates what Waiting for Superman does not, namely, that school reform, from TFA to $\mathrm{HCZ}$, is much more about lowering labor costs than about raising test scores, and that what Jeffrey Canada wants Superman to do is also what billionaire reformers like Bill and Melinda Gates want him to do: bust the union.

Thus, the little band of Harvard idealists going off to teach for America, like the much larger band going off to sell CDOs for Goldman Sachs, are making their own contribution to the reproduction and intensification of inequality in America. The Wall Street materialists contribute the old-fashioned way, by making a lot of 
money; the job of the TFA idealists - to make public school employees ("Several teachers have been fired...”) as disposable as college adjuncts - requires more virtue than greed. But both the materialists and the idealists have learned the fundamental lessons of American higher education very well. There's no injustice at Goldman Sachs as long as women and bankers of color get their fair share, and there's no injustice in turning as many college teachers as possible into underpaid adjuncts as long, once again, as women and people of color are proportionally represented on what's left of the tenure track. The general rule of American upperclass life is that inequality is not a problem except when it comes to race and sex; the application of that rule to American colleges is the call for faculty diversity.

\section{Literatura}

American Association of University Professors. (2009). The Annual Report on the Economic Status of the Profession, 2008-2009. "Academie" March-April: 13-93

American Association of University Professors. (2010). Tenure and Teaching-Intensive Appointments (2010), http://www.aaup.org/AAUP/ comm/rep/conversion.htm

Bennett P.R., Lutz A. (2009). How African American is the Net Black Advantage? Differences in College Attendance Among Immigrant Blacks, Native Blacks, and Whites. "Sociology of Education" 82 (1): 70-100

Charles C.Z., Roscigno V.J., Torres K.C. (2007). Racial Inequality and College Attendance: The Mediating Role of Parental Investments. "Social Science Research" 36 (1): 329-52

Dervarics Ch. (2010). Public Colleges Do Poor Job with Minority, Low-Income Students, Study Says. "Diverse: Issues in Higher Education" January 14, http://diverseeducation.com/article/13316

Douthat R. (2010). Grading School Choice. "New York Times" October 10. http://www.nytimes. com/2010/10/11/opinion/11douthat.html?_r=1

Faust D.G. (2007). Installation Address: Unleashing Our Most Ambitious Imaginings. http://www. president.harvard.edu/speeches/faust/071012_installation.php

Faust D.G. (2008). Baccalaureate Address to Class of 2008. http://www.president.harvard.edu/ speeches/ faust/080603_bacc.php. Grutter v. Bollinger, et al. "U.S. Supreme Court" No. 02241, June 23, 2008

Heilig J.V., Jez S.J. (2010). Teach For America: A Review of the Evidence. East Lansing, MI: The Great Lakes Center for Education Research and Practice

June A.W. (2009). Full-Time Instructors Shoulder the Same Burdens That Part-Timers Do. "Chronicle of Higher Education" October 18, http://chronicle.com/article/Full-Time-Instructors -Shoulder/48841

Kahlenberg R.D. (2007). Invisible Men. "Washington Monthly” March: 61-63.

Kahlenberg R.D. (2010). Disadvantages. "The New Republic" March 3, http://www.tnr.com/ book/review/disadvantages

Leonhardt D. (2004). As Wealthy Fill Top Colleges, Concerns Grow Over Fairness. "New York Times" April 22, http://www.nytimes.com/2004/ 04/22/us/as-wealthy-fill-top-collegesconcerns-grow-over-fairness.html? scp=2\&sq=\&st=nyt 
The Trouble with Diversifying the Faculty. (2011). "Liberal Education" (Winter). 4/8/11 4:54 PM http://www.aacu.org/liberaleducation/le-wi11/LEWI11_Michaels.cfm p. 7 of 8

Mangan D. (2010). Boys Club Bashed: Suit Alleges Goldman Bias Against Female Staffers, "New York Post" September 16, http://www.nypost.com/p/news/business/boys_club_bashed_4e oUzsuGdcoXVQn8TYMmoK\#ixzz143I0fT7o

Modern Language Association. (2008). Education in the Balance: A Report on the Academic Workforce in English. New York

Otterman S. (2010a). Harlem Children's Zone Gets \$20 Million Gift. "New York Times" September 16, http://cityroom.blogs.nytimes.com/2010/09/ 16/harlem-childrens-zone-gets-20million-gift

Otterman S. (2010b). Lauded Harlem Schools Have Their Own Problems. "New York Times" October 13, http://www.nytimes.com/2010/10/13/education/13harlem.html?pagewante.

Pryor J.H., Hurtado S., Saenz V.B., Santos J.L., Korn W.S. (2007). The American Freshman: FortyYear Trends 1966-2006. Los Angeles

QS. Graduate \& MBA Recruiting at Goldman Sachs, http://www.topmba.com/articles/graduatemba-recruiting-goldman-sachs

Reed A., Jr. (2009a). The 'Color Line' Then and Now: The Souls of Black Folk and the Changing Context of Black American Politics. [In:] Renewing Black Intellectual History: The Ideological and Material Foundations of African American Thought, ed. by A. Reed, Jr. and K.W. Warren. Boulder, CO

Reed A., Jr. (2009b). The Limits of Anti-racism. “Left Business Observer” 121, September, http:// www.leftbusinessobserver.com/Antiracism.html

Teach for (Some of) America: Too Talented for Public Schools. "Wall Street Journal" April 29, http://online.wsj.com/article/SB124061253951954349.html

This Year's Freshmen at 4-Year Colleges: Highlights of a Survey. "Chronicle of Higher Education". http://chronicle.com/article/This-Years-Freshmen-at-4-Year/63672

US College Search. Northwestern University. http://www.uscollegesearch.org/northwesternuniversity.html

US College Search. University of Illinois at Urbana-Champaign. http://www.uscollegesearch. org/university-of-illinois-at-urbanachampaign.html

Vault. Banking Employers Rankings 2011: Vault Banking 50, http://www.vault.com/wps/portal/ usa/rankings/methodology? rankingId $1=251$ \&rankingId $2=251$ \&rankingYear $=2011$ \&rank ings $=1$

\section{Kłopoty ze zróżnicowaniem wydziału}

Streszczenie

Powszechne przekonanie, że wydziały amerykańskich koledży i uniwersytetów muszą stać się bardziej zróżnicowane, jest powiązane z poczuciem, że studiujący na nich nie tworzą jednorodnej grupy, co zresztą jest prawdą. W 1971 roku wśród studentów pierwszego roku przeważali biali - 90,9\%, 7,5\% to studenci czarnoskórzy; Azjaci i Latynosi stanowili zaś 0,6\%, będąc praktycznie na tym tle niewidoczni. Oczywiście, te liczby nie oddają w pełni sytuacji: mężczyźni i kobiety pochodzenia latynoskiego są bardzo słabo reprezentowani, a studenci czarnoskórzy to nadal jedynie nieznaczna grupa. Ponadto, jeśli uwzględnimy dane pochodzące z koledży o bardziej selekcyjnej polityce naboru, liczba nawet $11 \%$ czarnoskórych studentów wydaje się być 
nieco zawyżona. I tak na przykład na koledżu Northwestern studenci czarnoskórzy stanowią jedynie 5\%, University of Illinois w Urbana-Champaign jest bliższe 7\% (wg statystyk US College Search). Tak więc w tym przypadku czarnoskórzy są znacząco słabo reprezentowani.

Taka sytuacja nie wynika jednak z selekcji ze względu na kolor skóry. Wręcz przeciwnie, jest to wyraz tego, co badacze tematu nazywają „czarną przewagą sieciową", gdy „podstawowe ekonomiczne różnice zostały pominięte”. Afroamerykanie częściej uczęszczają do czteroletnich koledży niż biali studenci, uniwersytety nie marginalizują bowiem studentów pochodzących z grup mniejszościowych, lecz studentów ubogich. Faktycznie, wzrost zróżnicowania w kształceniu wyższym przez ostatnich czterdzieści lat był zgodny ze wzrostem dobrobytu. W 1971 roku średni dochód studentów pierwszego roku w 297 koledżach uczestniczących w badaniach American Freshman Survey wynosił $46 \%$ ponad średnią krajową.

$\mathrm{Z}$ tego też powodu pytanie, kto powinien studiować na wydziałach, jest jednocześnie pytaniem o to, kto powinien nauczać bogate dzieci, pomimo że nikt nie domagał się nigdy, by grupa profesorów była tak samo zróżnicowana jak grupa studentów oraz tak samo zamożna; płace nauczycieli akademickich faktycznie wzrosły. I tak na przykład na moim uniwersytecie, University of Illinois w Chicago, adiunkci zatrudnieni na dziewięciomiesięcznych kontraktach, nauczający sześć kursów rocznie, zarabiają pomiędzy 26788 a 30900 USD. Według „Chronicle of Higher Education” jest to pensja „wysoka w grupie pracowników, którzy pracują poza systemem stałego zatrudnienia w regionie" (czerwiec 2009). Ponadto, od kiedy adiunkci nieposiadający żadnych zobowiązań badawczych mają przydzieloną większą liczbę godzin dydaktycznych niż na wydziałach zatrudniających na pełny etat, prowadzone przez nich zajęcia kursowe składają się w większości z treści nauczanych także na naszym wydziale.

Moi koledzy analizują częściej to, czy grupa studentów jest wystarczająco zróżnicowana, niż to, jak jest ona zamożna; również są bardziej zainteresowani zróżnicowaniem samego wydziału niż stanem majątkowym jego pracowników. Na Uniwersytecie Chicagowskim na przykład jesteśmy tak oddani idei „Zwiększania liczby niedoreprezentowanych wydziałów”, iż zatrudniamy urzędników, którzy w tych trudnych czasach starają się jak najlepiej poświęcać uhonorowaniu tejże idei. Nie możemy się pochwalić zbyt wieloma wejściami w wyszukiwarkach internetowych; jeśli już się pojawiają, odnoszą się do uczonych z obszarów specjalistycznych związanych $\mathrm{z}$ badaniami nad rasą, jak np. studia afroamerykańskie czy też literatura latynoamerykańska, czyli prawdopodobnie kandydat na studia ucieleśnia na równi z wykładowcami obiekt swoich studiów. Jednak większość zajęć dydaktycznych będzie prowadzona przez ludzi, których wynagrodzenie jest zbliżone do średniej, a kolor skóry nieistotny. Zalety tego rodzaju dwustopniowej profesury są zatem w równym stopniu materialne, jak i moralne. Na samym dole hierarchii społeczności wydziału znajdujemy uelastycznienie siły roboczej, na samej górze zaś jej dywersyfikację. Pomimo iż najniższy poziom dochodów obecnie nie zbliża się nawet do stanu zróżnicowania poziomu najwyższego, nie jest to poważnym problemem, odkąd żaden przedstawiciel danej grupy rasowej nie chce przynależeć do warstwy znajdującej się najniżej $\mathrm{w}$ strukturze tej instytucji. Sukces w tym przypadku polega jedynie na zróżnicowaniu elity i, co za tym idzie, realizacji „amerykańskiego snu”.

W tym kontekście możemy rozpoznać fundamentalnie konserwatywny i antyegalitarny charakter wezwania do zróżnicowania wydziału i całego amerykańskiego systemu uniwersyteckiego. Oznacza to, że próba otwarcia uniwersytetu na ludzi kolorowych odniosła zwycięstwo nad próbą otwarcia się na ludzi bez pieniędzy. Mogą istnieć konstytucyjne zastrzeżenia co do polityki rekrutacyjnej opartej na kryteriach rasowych i dyskryminującej białych kandydatów, lecz z pewnością nie ma żadnych prawnych obiekcji wobec polityki preferującej zamożnych kandydatów. Faktycznie, nasze uniwersytety, pomimo że są uważane za najbardziej liberalne 
instytucje, stanowią takie same amerykańskie instytucje wyższej klasy średniej jak wszystkie inne. Nikt nie myśli serio o bankach jako o instytucjach liberalnych, lecz coroczny ranking „50 najbardziej prestiżowych firm bankowych” włącza do swoich kryteriów oceny problem zróżnicowania, a firmą numer jeden (zarówno pod względem zróżnicowania, jak i w ogólnej ocenie) okazała się firma Goldman Sachs. Zarządzający uniwersytetami zastanawiają się nad faktem, który prezydent Draw Faust (2008) z Uniwersytetu Harvardzkiego ujęła jako „stałe zasilanie naszymi absolwentami sfery finansów, konsultingu i bankowości internetowej”. Trudno jednak się dziwić. Bądź co bądź to właśnie prezydent Faust podczas swojej inauguracji pogratulowała naszym uniwersytetom bycia siłą napędową „ekspansji obywatelskości, równości i szansy dla czarnych, kobiet, Żydów, imigrantów i innych" (2007). Jednakże wiemy już, kim są owi inni. Jedyna różnica pomiędzy bankami a uniwersytetami polega na tym, że, jak ujmuje to Goldman Sachs, ich celem jest czynienie młodzieży jeszcze bardziej zamożnej, nie zaś docenianie zróżnicowania. Dążą one do zdobycia „globalnej bazy klientów odzwierciedlającej wielość kultur” i „wywierają na nie nacisk” (QS). Tak więc, jeśli 39\% absolwentów Harvardu zasila sektor bankowy i finansowy, nie jest to niczym niezwykłym. Dzieje się tak, ponieważ odrobili oni bardzo dobrze lekcję społecznej sprawiedliwości (lekcję zróżnicowania grupy studentów i samych wydziałów), których nauczył ich Harvard, i będą walczyć równie zaciekle, by przekuć je na rzeczywistość na Wall Street w takim stopniu, jak czynili to w Cambridge.

$\mathrm{Z}$ tego powodu mała grupa idealistów opuszczająca mury Harvardu, by nauczać w Ameryce, podobnie jak znacznie większa grupa, która będzie sprzedawać aktywa dla Goldman Sachs, na swój własny sposób przyczynia się do powielania i intensyfikacji nierówności w Ameryce. Materialiści z Wall Street z kolei przyczyniają się do tego samego w znany już sposób - zarabiając dużo pieniędzy. Zadaniem idealistów z Teach for America jest zostać pracownikami szkół publicznych („Kilku nauczycieli zostało zwolnionych...”), tak samo zbędnymi jak adiunkci na uniwersytetach, co wymaga bardziej cnoty umiaru niż chciwości. Jednak zarówno materialiści, jak i idealiści bardzo dobrze przyswoili sobie podstawowe lekcje $\mathrm{z}$ amerykańskiego systemu szkolnictwa wyższego. W Goldman Sachs nie ma niesprawiedliwości tak długo, jak kobiety i nie-biali bankierzy dostają swój sprawiedliwy udział w zyskach. Nie ma także niesprawiedliwości w zmienianiu jak największej liczby nauczycieli akademickich w nisko opłacanych adiunktów tak długo, jak długo kobiety i kolorowi są proporcjonalnie reprezentowani w tym, co zostało z systemu etatowego. Ogólna zasada życia amerykańskiej klasy wyższej brzmi bowiem następująco: nierówność nie jest problemem z wyjątkiem sytuacji, w których chodzi o kwestie rasowe lub płeć. Zastosowanie tej zasady w amerykańskich koledżach jest zaś wezwaniem do zróżnicowania wydziałów. 
